\title{
Molecular Interactions and Functional Interference between Vitronectin and Transforming Growth Factor- $\beta$
}

\author{
Michael Schoppet, Triantafyllos Chavakis, Nadia Al-Fakhri, Sandip M. Kanse, and \\ Klaus T. Preissner \\ Department of Biochemistry (MS, TC, SMK, KTP), 3rd Department of Internal Medicine (TC), and Department of \\ Clinical Chemistry (NA-F), Medical Faculty, Justus-Liebig-University, Giessen, Germany
}

\begin{abstract}
SUMMARY: Different extracellular matrix proteins have been described as binding proteins for growth factors, influencing their storage or presentation towards cellular receptors. The multifunctional adhesive glycoprotein vitronectin (VN), which is found in the circulation and widely distributed throughout different tissues, has been implicated in the regulation of vascular cell functions, and these activities could be related to interactions with various growth factors. In vitro, soluble VN interfered with transforming growth factor- $\beta$ (TGF- $\beta$ ) binding to isolated extracellular matrix and was found to associate with TGF- $\beta 1$ and TGF- $\beta 2$ as well as with other growth factors such as vascular endothelial growth factor, epidermal growth factor, or basic fibroblast growth factor in a saturable manner. In particular, binding of TGF- $\beta$ was maximal for the heparin-binding multimeric isoform of VN, whereas VN in a ternary complex with thrombin and antithrombin or plasma VN exhibited weaker binding. Plasminogen activator inhibitor-1 (PAl-1) or heparin, but not desulfated glycosaminoglycans, interfered with binding of VN to TGF- $\beta$, and soluble PAI- 1 was able to dissociate VN-bound TGF- $\beta$. Upon limited plasmin proteolysis of VN, only the fragments comprising the intact aminoterminal portion of VN bound to TGF- $\beta$ as did a synthetic peptide (amino acids 43 to 62 ), indicating that TGF- $\beta$ and PAI- 1 share common binding site(s) on VN. Although VN did not influence TGF- $\beta$ bioactivity for mink lung epithelial cells, TGF- $\beta$ dose dependently inhibited both urokinase-receptor as well as $\alpha_{\mathrm{v}}$-integrin-dependent adhesion to VN. This activity of TGF- $\beta$ was reminiscent of the antiadhesive function of PAI-1. In atherosclerotic tissue sections, staining patterns of VN and TGF- $\beta$ indicated their colocalization. These findings describe VN as a new binding protein for TGF- $\beta$, whereby specific functions of both factors become modulated by this interaction. (Lab Invest 2002, 82:37-46).
\end{abstract}

$T$ he extracellular matrix (ECM) is a complex structural network consisting of different collagens, sulfated proteoglycans, and adhesive glycoproteins, to which various factors are bound, which dynamically regulate cellular growth, morphogenesis, and differentiation. Among these, growth factors, proteases, and their specific inhibitors not only influence the molecular composition of the ECM but organize motility of cells and their invasiveness. The earliest reports on tethering of growth factors to the ECM included the fibroblast growth factor family (Rapraeger et al, 1991), demonstrating anchoring of these polypeptides to the polysaccharide component of heparan sulfate proteoglycans. In addition, binding of basic fibroblast growth factor (bFGF) to cell surface-associated heparin-like molecules is required for binding of the growth factor to its high-affinity receptor, thus serving as a dual receptor system for full growth factor activity (Klags-

Received September 17, 2001.

This study is part of the thesis by Michael Schoppet at the Medical Faculty, Justus-Liebig-Universität, Giessen, Germany. This study was supported in part by Grant Pr 327/1-4 from the Deutsche Forschungsgemeinschaft, Bonn, Germany, and the Wilhelm-Sander-Stiftung, Munich, Germany. Address reprint requests to: Dr. Klaus T. Preissner, Medical Faculty, Department of Biochemistry, Justus-Liebig-Universität, Friedrichstrasse 24, D-35392 Giessen, Germany.E-mail: klaus.t.preissner@biochemie.med.uni-giessen.de brun and Baird, 1991; Roghani et al, 1994; Yayon et al, 1991). Other factors, such as vascular endothelial growth factor (VEGF), which act as paracrine signal molecules, also associate with heparan sulfate polysaccharides by virtue of their heparin-binding properties (Neufeld et al, 1999). Bound growth factors directly interact with cells or become trapped within the ECM until hydrolytic enzymes release the bound polypeptides that subsequently gain excess to their target cells. Several proteins bound to the ECM or to cell surfaces are thought to interact with such growth factors and serve to deposit and concentrate them locally. Examples of such interactions are transforming growth factor- $\beta$ (TGF- $\beta$ ) and thrombospondin (Murphy-Ullrich et al, 1992), platelet-derived growth factor-AB or -BB and SPARC (secreted protein, acidic and rich in cysteine; Raines et al, 1992), or heparinbinding growth factor-1 and fibronectin (Kan and Shi, 1990).

Another multifunctional adhesive glycoprotein is vitronectin (VN), found in the circulation and deposited in several tissues, particularly during wound healing in the vessel wall and the skin (Preissner, 1991). A high degree of conformational flexibility leads to the generation of isoforms of the molecule with heparinbinding (François et al, 1999) and other exposed domains, which are thought to endow the protein with 
multivalent properties, particularly when associated with the ECM (Bittdorf et al, 1993; Stockmann et al, 1993). Because of its interaction with different receptor systems, such as the urokinase receptor (UPAR) or integrins, VN serves as a versatile adhesion molecule at sites of tissue remodeling. For example, leukocyte adhesion to $\mathrm{VN}$, which is involved in the recruitment of these cells to the inflamed tissue, is greatly dependent on UPAR. In this case, urokinase plasminogen activator (UPA) acts as a proadhesive factor by increasing the affinity of the uPAR-VN interaction, whereas plasminogen activator inhibitor-1 (PAl-1), which is bound and stabilized by VN (Declerck et al, 1988), serves as an antiadhesive factor (Kjoller et al, 1997). Independent of its antiproteolytic activity, PAl-1 can block integrin-mediated adhesion to VN as well (Stefansson and Lawrence, 1996), a process that is important in the regulation of vascular cell migration. $\mathrm{VN}$ and its fragments as well as integrins with specificity for VN are found in areas of inflammation and angiogenesis (Casaroli Marano et al, 1995; Kramer et al, 1993), and the detection of these components in atherosclerotic lesions was reported (Mori et al, 1995). Limited proteolysis of VN by plasmin converts the ECM protein into a plasminogen-binding factor (Kost et al, 1992), which contributes to the dynamics of cell-ECM contacts (Ciambrone and McKeown-Longo, 1990).

TGF- $\beta 1-3$ are cytokines involved in inflammation, proliferation, angiogenesis, apoptosis, and ECM production relevant in vascular regeneration and remodeling (Massague, 1998; Munger et al, 1997). Synthesized by cells in a latent dimeric form and noncovalently complexed to the latency-associated peptide (Massague, 1990), latent TGF- $\beta$ must be activated to elicit biologic responses or to bind to their cognate cell surface receptors (Munger et al, 1997). Latent TGF- $\beta$ is found associated with the latent TGF- $\beta$-binding protein, which confers binding to the ECM and seems to associate with uPAR (Godar et al, 1999), leading to possible TGF- $\beta$ activation or UPAR recycling.

In the present study, we investigated the interaction of TGF- $\beta$ with VN and could define binding characteristics in vitro. In addition, we studied possible functional consequences of this physical interaction in different cell culture systems, and atherosclerotic tissue sections were investigated for colocalization of both components. The results indicate that binding of TGF- $\beta$ to ECM-resident VN or VN in the circulation mutually influences the bioactivity of both factors, particularly related to cell adhesion phenomena.

\section{Results}

\section{Binding of TGF- $\beta$ to ECM}

Binding of TGF- $\beta 1$ to the ECM of cultured endothelial cells was tested in the absence or presence of various soluble competitors such as plasma VN, fibronectin, fibrinogen, or heparin. Although VN inhibited binding of TGF- $\beta 1$ to ECM in a concentration-dependent manner, fibronectin and fibrinogen did not interfere with binding of TGF- $\beta$ to the ECM (Fig. 1). High concentrations of heparin exhibited a moderate blockade of TGF- $\beta 1$ binding to ECM.

\section{Binding of VN to Various Immobilized Peptide Growth Factors and Binding of Different VN Isoforms to TGF- $\beta$}

In addition to TGF- $\beta$, several heparin-binding growth factors including VEGF, epidermal growth factor (EGF), and bFGF were tested in their ability to bind to plasma VN in an ELISA system (Fig. 2A). Because TGF- $\beta$ exists in humans in several isoforms (TGF- $\beta 1$ $3)$, we tested TGF- $\beta 1$ and TGF- $\beta 2$ for interaction with VN but found no difference in the binding pattern of the isoforms. These data revealed that growth factors varied in their extent of binding to VN, EGF representing the highest capacity, whereas bFGF was bound less effectively. Furthermore, different isoforms of $\mathrm{VN}$ (plasma VN, multimeric VN, ternary complex) were studied for binding to immobilized TGF- $\beta 1$. The most prominent binding was seen with multimeric VN, whereas the ternary complex and plasma VN exhibited less efficient binding (Fig. 2B). The binding constants (derived from double reciprocal plots) were estimated to be $0.33 \mathrm{~nm}$ for multimeric VN, $2.6 \mathrm{~nm}$ for the ternary complex, and $7.3 \mathrm{~nm}$ for plasma VN.

\section{Competition of VN-Growth Factor Interactions by Glycosaminoglycans and by PAI-1}

To characterize the binding domains of $\mathrm{VN}$ involved in the interaction with growth factors, different glycosaminoglycans were studied for their ability to interfere with binding of $\mathrm{VN}$ to immobilized growth factors, particularly TGF- $\beta 1$. Heparin blocked binding of multimeric VN to immobilized TGF- $\beta 1$ and EGF (data not shown) as did SP-54, a highly sulfated and negatively charged pentasaccharide, whereas dermatan sulfate and desulfated heparin failed to interfere with binding

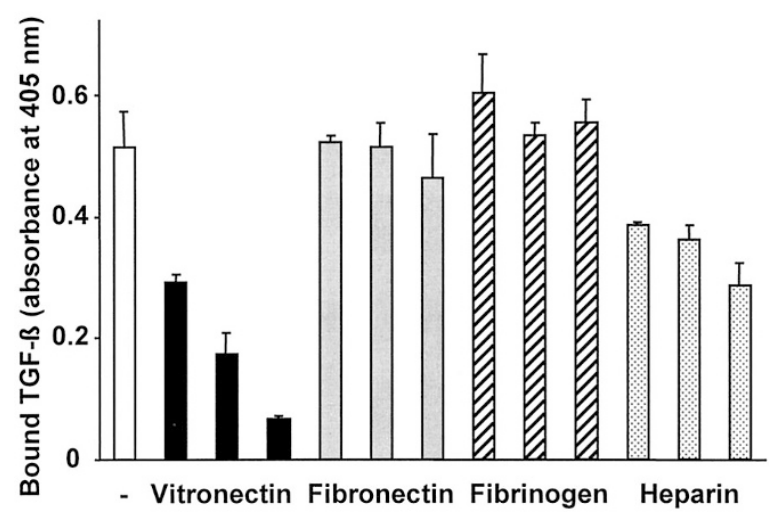

Figure 1.

Binding of transforming growth factor- $\beta 1$ (TGF- $\beta 1$ ) to HUVEC-derived extracellular matrix (ECM). After preincubation (from left to right) of plasma vitronectin (2, 10, and $20 \mu \mathrm{g} / \mathrm{ml})$, fibronectin (2, 10, and $20 \mu \mathrm{g} / \mathrm{ml})$, fibrinogen $(2,10$, and $20 \mu \mathrm{g} / \mathrm{ml})$, heparin $(20,100$, and $200 \mu \mathrm{g} / \mathrm{ml})$, or buffer alone (open bar) with TGF- $\beta(0.5 \mu \mathrm{g} / \mathrm{ml})$ for 30 minutes at $37^{\circ} \mathrm{C}$, the individual mixtures were allowed to react with isolated ECM derived from cultured endothelial cells. Bound TGF- $\beta$ was quantitated by antibody detection, expressed as absorbance at $405 \mathrm{~nm}$. Data are mean $\pm \operatorname{SEM}(n=3)$ of a typical experiment, out of three similar ones. 


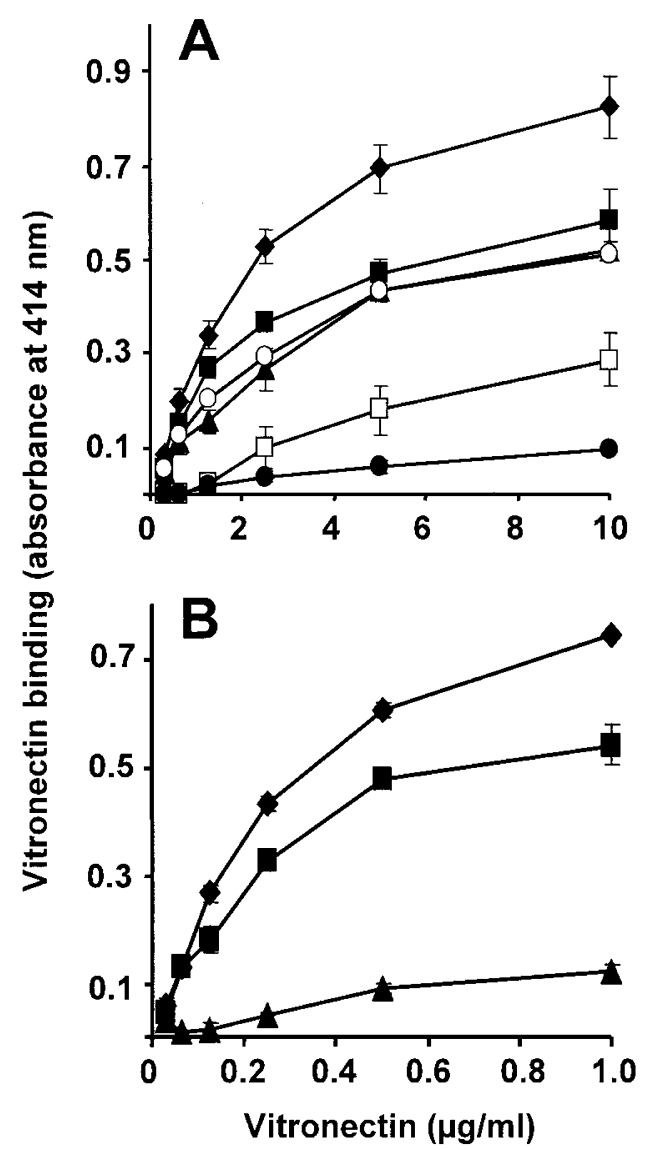

Figure 2.

Binding of soluble plasma vitronectin (VN) to immobilized growth factors and binding of different vitronectin isoforms to immobilized TGF- $\beta$. A, TGF- $\beta 1$ ( $(\mathbf{\Lambda})$, TGF- $\beta 2(O)$, vascular endothelial growth factor (VEGF) (ם), epidermal growth factor (EGF) ( ), basic fibroblast growth factor (bFGF) ( $\square$ ), and, for control, fibrinogen (๑) were immobilized in microtiter wells, and soluble plasma VN at the indicated concentrations was allowed to bind. B, Different isoforms of VN, ie, plasma VN $(\boldsymbol{\Delta})$, multimeric VN $(\bullet)$, or the ternary VN-thrombinantithrombin complex ( $\mathbf{\square})$, were allowed to bind to immobilized TGF- $\beta 1$. For ELISA detection, a monoclonal anti-VN antibody (VN7) and the respective peroxidase-conjugated secondary antibody were used to quantitate bound VN, expressed as absorbance at $414 \mathrm{~nm}$.

of $\mathrm{VN}$ to growth factors (Fig. 3A). These results indicate that either the heparin-binding site in VN or the oppositely charged aminoterminus of the protein is involved in the described interaction. To specify these observations, PAl-1 was included in inhibition experiments, because the high-affinity binding site of the inhibitor is located within the acidic aminoterminal portion of VN. Although the latent form of PAI-1, which hardly binds to $\mathrm{VN}$, had no effect on the interaction between multimeric VN and immobilized TGF- $\beta 1$ or EGF (data not shown), active PAI- 1 had a similar and comparable inhibitory effect on TGF- $\beta$ binding as was demonstrated for heparin (Fig. 3B). No binding of active PAl- 1 to immobilized TGF- $\beta 1$ or EGF could be detected (data not shown), indicating that the PAl-1 binding site in $\mathrm{VN}$ was engaged in binding to these peptide growth factors. Two-chain high molecular weight kininogen $(\mathrm{HKa})$, which also binds to the aminoterminus of $\mathrm{VN}$ and competes with PAl-1 for the same binding site on VN, was tested but did not inhibit
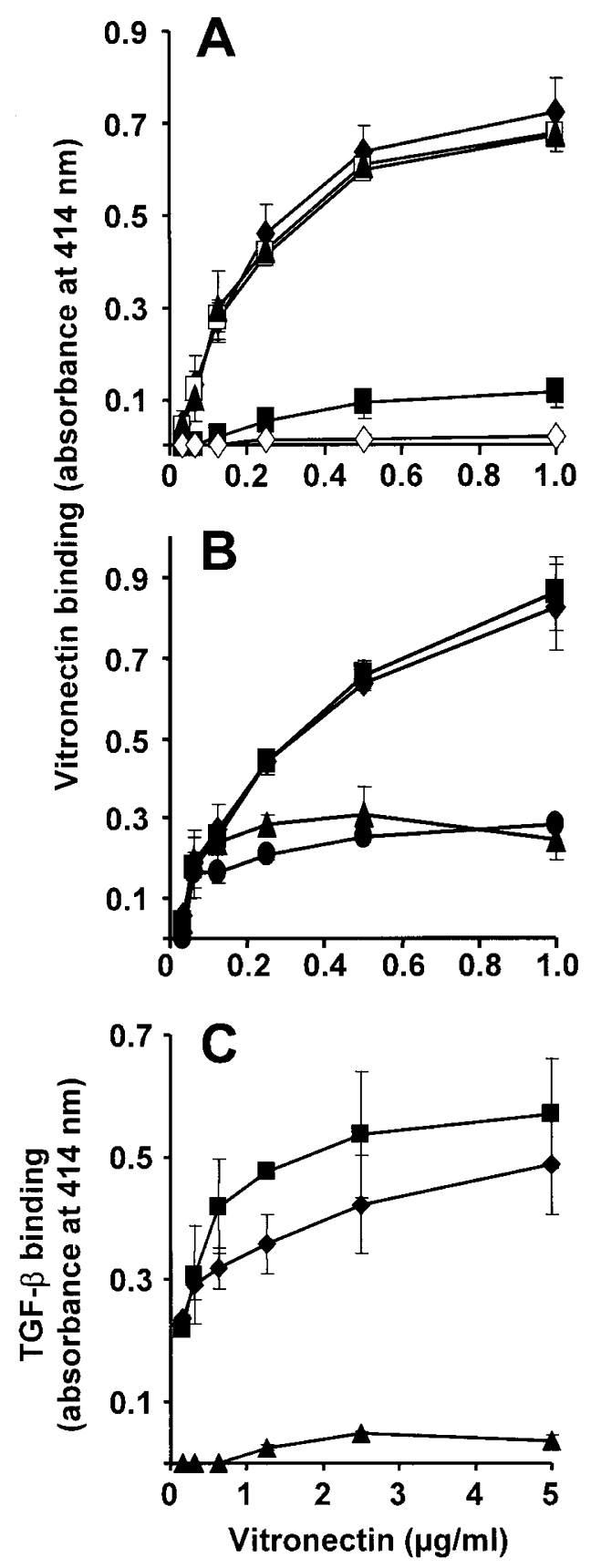

Figure 3.

Vitronectin binding to growth factors: competition by glycosamino-glycans and plasminogen activator inhibitor-1 (PAl-1). A, Soluble multimeric VN was allowed to bind to immobilized TGF- $\beta 1$, which was preincubated for 15 minutes with buffer only $(\bullet)$ or $100 \mu \mathrm{g} / \mathrm{ml}$ each of heparin $(\square)$, desulfated heparin $(\square)$, dermatan sulfate $(\mathbf{\Lambda})$, SP-54 $(\diamond)$, or (B) buffer only $(\bullet)$, or heparin $(100 \mu \mathrm{g} / \mathrm{ml})(\bullet)$, as well

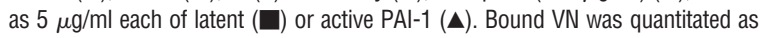
described in the legend to Figure 2. C, In the reverse system, binding of soluble TGF- $\beta 1$ to immobilized VN in the absence ( $)$ or the presence of heparin (100 $\mu \mathrm{g} / \mathrm{ml}$ ) was performed, whereby heparin was preincubated with immobilized VN and either left in the binding mixture $(\mathbf{\Lambda})$ or unbound heparin was washed away (荞 before addition of TGF- $\beta$. Quantitation of bound TGF- $\beta$ was measured with the respective antibody detection system and expressed accordingly as indicated for VN in the legend to Figure 2.

the interaction between TGF- $\beta$ and VN (data not shown). In a reverse manner, soluble TGF- $\beta 1$ was found to bind to immobilized plasma VN as well, and 
blocking of growth factor binding could be achieved by preincubating immobilized VN with heparin before the addition of TGF- $\beta$. In contrast, no competition was observed if unbound heparin was thoroughly removed before TGF- $\beta$ was added (Fig. 3C).

\section{Binding of VN-Derived Fragments and Peptides to TGF- $\beta 1$}

To complement these data, binding of TGF- $\beta 1$ was tested to proteolytic fragments of $\mathrm{VN}$ derived after limited digestion with plasmin. Taking into account that the carboxyterminal portion of the VN molecule comprising the heparin binding region is most sensitive to plasmin proteolysis, initial fragments of 65-, 61to 63-, and 56-kd containing an intact aminoterminus of VN were generated. Subsequently, the 56-kd fragment was further degraded into fragments of 42 and $35 \mathrm{kd}$. Only the initial larger fragments, but not these shorter peptides, were able to interact with TGF- $\beta$ in a ligand blot assay (Fig. 4, A and B), supporting the previous results that the aminoterminus of $\mathrm{VN}$ comprises the binding region for TGF- $\beta$. Synthetic peptides of this region of $\mathrm{VN}$ with overlapping sequences between amino acids 1 to 130 were tested for binding
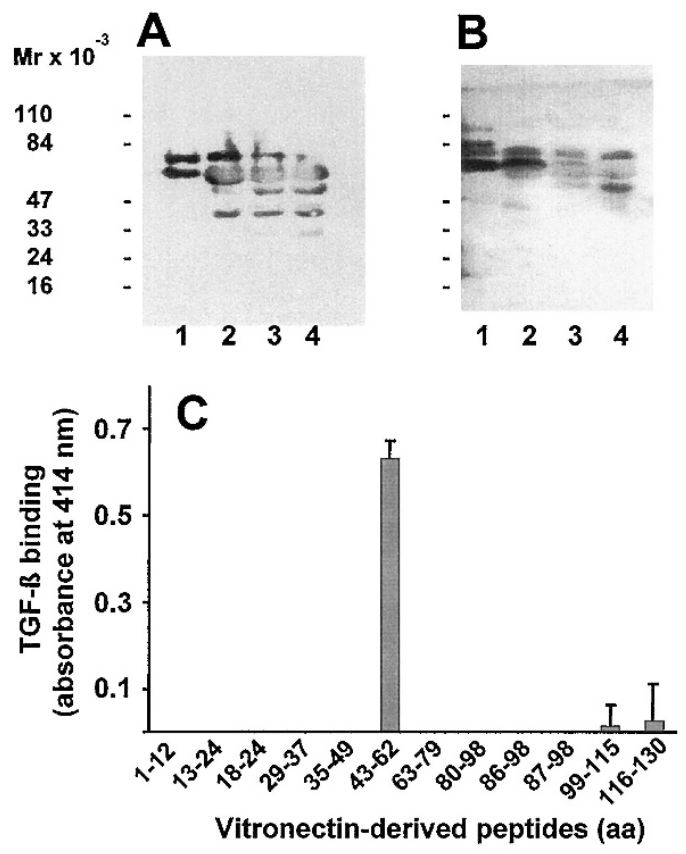

Figure 4.

Binding of TGF- $\beta$ to VN-derived fragments. Undegraded VN (Lanes 1 ) and VN fragments derived from limited plasmin proteolysis for 10 minutes (Lanes 2), 30 minutes (Lanes 3), or 1 hour (Lanes 4) were separated by SDSpolyacrylamide gel electrophoresis, transferred onto nitrocellulose and (A) stained by immunoblotting with the anti-S6/7 polyclonal VN antibody, (B) incubated with soluble TGF- $\beta 1$ followed by the addition of a monoclonal anti-TGF- $\beta$ antibody. In both cases a secondary antibody system and substrate was used to stain respective bands as indicated in the "Materials and Methods" section. C, Synthetic peptides (2 $\mu \mathrm{g} / \mathrm{ml}$ each) of the aminoterminal region (1 to 130) of the VN molecule comprising the indicated overlapping amino acid (aa) sequences were immobilized using the Covalink system, and TGF- $\beta 1$ (100 $\mathrm{ng} / \mathrm{ml}$ ) was allowed to bind. Bound TGF- $\beta$ was quantitated as indicated in the legend to Figure 3 . Values represent mean $\pm \operatorname{SEM}(n=3)$ of a typical experiment, out of three similar ones. to TGF- $\beta$. Only one peptide of this series, entailing amino acids 43 to 62 , was able to bind soluble TGF- $\beta 1$ (Fig. 4C). These results confirm our initial observations that the aminoterminus of VN constitutes the binding site for TGF- $\beta 1$.

\section{Influence of VN on TGF- $\beta$ Activity}

To measure the influence of VN on TGF- $\beta$ bioactivity, different concentrations of active TGF- $\beta 1$ were preincubated with multimeric VN and thereafter added to mink lung epithelial cells (MLEC) transfected with a TGF- $\beta$-sensitive PAl-1 promotor construct (Fig. 5). Activation of cells induced by TGF- $\beta$, as measured by luciferase activity, did not significantly change in the presence of multimeric VN. We tested different concentrations of multimeric VN and different incubation times, but there was hardly any influence on the PAl-1 promotor-driven induction of luciferase by TGF- $\beta 1$, indicating that $\mathrm{VN}$ binding to TGF- $\beta$ did not affect its interaction to cellular receptor(s) and subsequent signal transduction events.

\section{Dissociation of the VN-TGF- $\beta$ Complex by Soluble PAI-1}

Because PAl-1 competes with TGF- $\beta$ for binding to $\mathrm{VN}$, we investigated whether preformed VN-TGF- $\beta$ complexes can be dissociated by an excess of soluble PAI-1. TGF- $\beta$ was allowed to bind to immobilized VN, followed by incubation with either PAI-1 or HKa. Although $\mathrm{HKa}$ did not interfere with $\mathrm{VN}$-growth factor complexes, consistent with the competition studies shown before, in a concentration-dependent manner, PAl-1 was able to release bound TGF- $\beta$ from VN to an appreciable degree (Fig. 6).

\section{Antiadhesive Activity of TGF- $\beta$ in Cell Adhesion}

The adhesion of leukocytic cells to VN is mediated by UPAR and augmented by uPA to increase the affinity

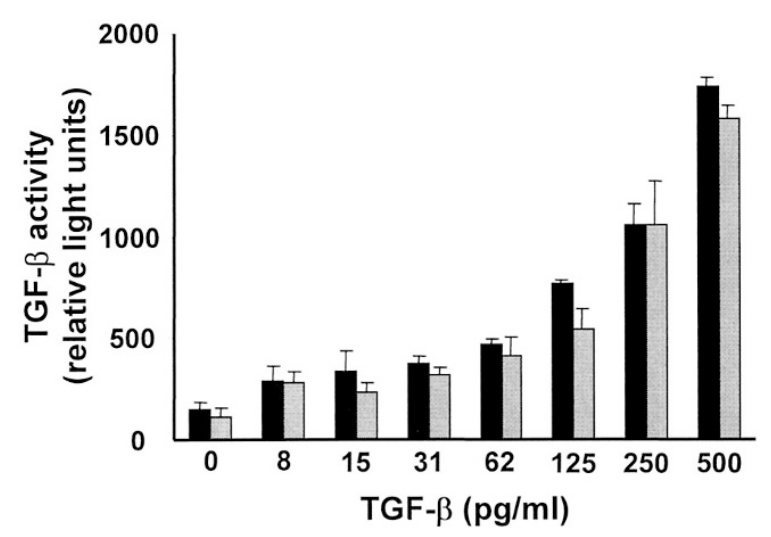

Figure 5.

Influence of VN on TGF- $\beta$ activity. Mink lung epithelial cells expressing the TGF- $\beta$-sensitive PAI- 1 promotor-driven luciferase construct were stimulated with the indicated concentrations of TGF- $\beta$, preincubated for 30 minutes at $37^{\circ} \mathrm{C}$ in the absence (black bars) or the presence of multimeric VN $(10 \mu \mathrm{g} / \mathrm{ml}$; grey bars). TGF- $\beta$ induced effects on MLEC were assessed by measuring photon emission (relative light units) generated from PAl-1 promotor coupled luciferase expression. The assay was performed in triplicates, mean values \pm SEM of a representative experiment $(n=3)$ are shown. 


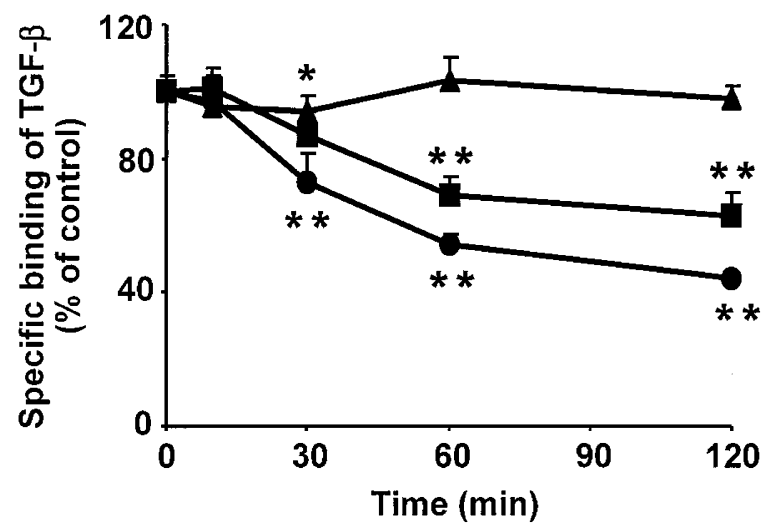

Figure 6.

Binding of TGF- $\beta$ to immobilized VN. TGF- $\beta(1 \mu \mathrm{g} / \mathrm{ml})$ was allowed to bind to immobilized VN $(2 \mu \mathrm{g} / \mathrm{ml})$ for 6 hours at $22^{\circ} \mathrm{C}$. Plates were then washed and $250 \mathrm{~nm} \mathrm{PAl}-1(\bullet), 100 \mathrm{~nm} \mathrm{PAl}-1(\boldsymbol{\square})$, or $250 \mathrm{~nm}$ two-chain high molecular weight kininogen (HKa) $(\mathbf{\Lambda})$ was added at different time points as indicated. Thereafter, the remaining TGF- $\beta$ was detected by a polyclonal antibody, followed by a secondary peroxidase-conjugated antibody against rabbit immunoglobulins. Specific binding of TGF- $\beta$ is shown as percent of control, which is represented by the binding of TGF- $\beta$ to VN in the absence of competitors. Values represent mean values \pm SEM of a typical experiment out of three; * $p$ $<0.03,{ }^{* *} p<0.0005$ compared with binding in the absence of PAl-1.

of the UPAR-VN interaction, whereas the adhesion of MG63 osteosarcoma cells to $\mathrm{VN}$ is dependent on $\alpha_{\mathrm{v}}$-integrins, as evidenced by inhibition studies with cyclic RGDfV peptide (Wong et al, 1996). Because TGF- $\beta 1$ bound to the 43 to 62 peptide region of VN, which is located proximal to the binding sites for PAl-1 and UPAR as well as the integrin recognition motif RGD, the effect of TGF- $\beta 1$ on VN-mediated cell adhesion was tested. BAF-3 (mouse B cells) transfected with UPAR adhered strongly to VN, and this adhesion was inhibited by an anti-uPAR monoclonal antibody R3 (Chavakis et al, 1999). In a similar manner, TGF- $\beta 1$ dose dependently inhibited cell adhesion both in the absence or the presence of uPA (Fig. 7A). Moreover, $\alpha_{\mathrm{v}}$-integrin-dependent MG63 cell adhesion to VN was inhibited by TGF- $\beta 1$, an antiadhesive activity that is comparable to the propensity of PAl-1 to block cell adhesion (and migration) on VN substrata (Fig. 7B). In contrast, MG63 cell adhesion to fibronectin, which is predominantly $\beta_{1}$-integrin mediated, was not affected by TGF- $\beta 1$, although TGF- $\beta$ may also bind to fibronectin. These latter data indicate that TGF- $\beta$ can act as a specific antiadhesive factor in different VN-dependent adhesion systems.

\section{Discussion}

Mechanisms for tethering growth factors to the ECM are of importance to concentrate them in the immediate proximity of cells with impact on biologic function in vivo. Not only binding and sequestration, but also modulation of growth factor activity, could result from their interaction with particular ECM components participating in the mechanisms of growth factor signaling (Klagsbrun and Baird, 1991). Besides binding of members of the fibroblast growth factor family to heparan sulfate proteoglycans (Yayon et al, 1991), several
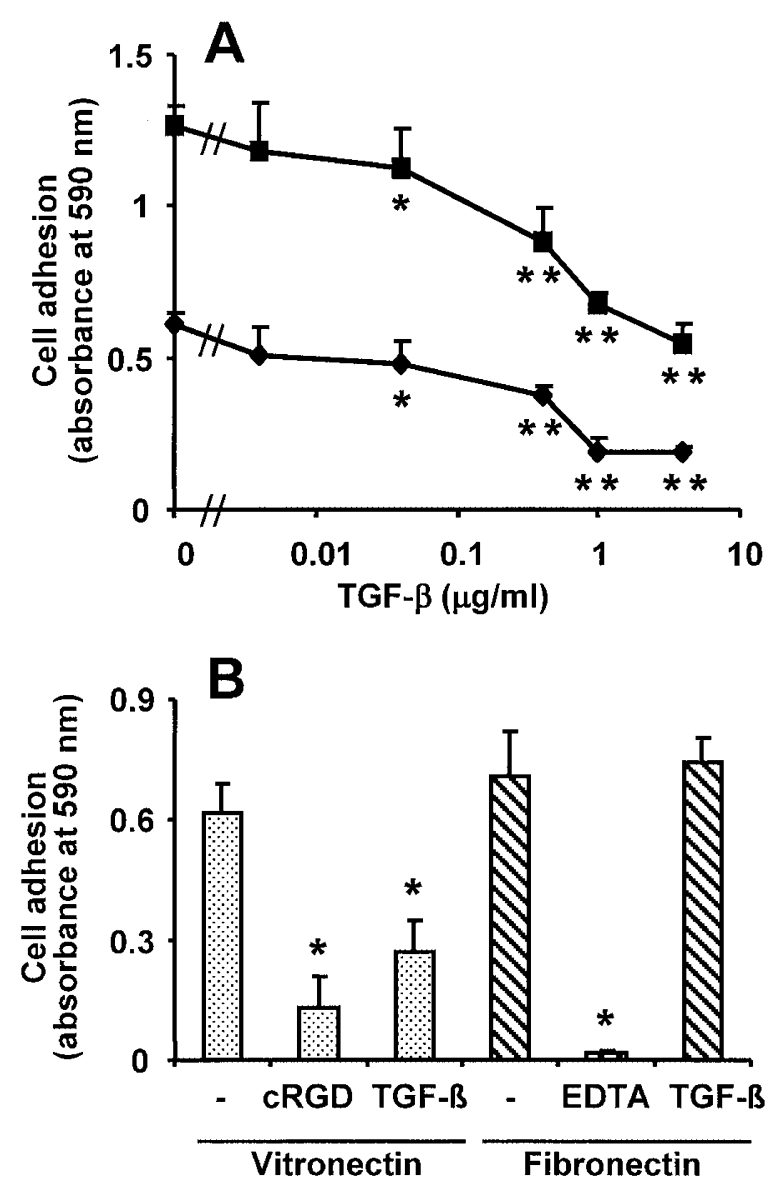

Figure 7.

Effect of TGF- $\beta 1$ on VN-dependent cell adhesion. A, The adhesion of urokinase receptor (UPAR)-transfected BAF-3 cells to VN in the absence $(\bullet)$ or presence (表 of $50 \mathrm{nmol} / \mathrm{L}$ urokinase plasminogen activator (UPA) without or together with increasing concentrations of TGF- $\beta 1$ as indicated was measured. Data are expressed as absorbance at $590 \mathrm{~nm}$ and are means $\pm \operatorname{SEM}(n=3)$ of a typical experiment out of three; ${ }^{*} p<0.02,{ }^{* *} p<0.002$ compared with adhesion in the absence of TGF- $\beta$. B, The integrin-dependent adhesion of MG63 cells to vitronectin (dotted bars) or fibronectin (hatched bars) in the absence (-) or presence of $2 \mu \mathrm{g} / \mathrm{ml}$ TGF- $\beta, 10 \mu \mathrm{g} / \mathrm{ml}$ cyclic RGD peptide, or $10 \mathrm{mmol} / \mathrm{L}$ EDTA is shown. Data are expressed as absorbance at $590 \mathrm{~nm}$ and are means \pm SEM $(n=3)$ of a typical experiment. Similar results were obtained in three separate experiments; * $p<0.01$ compared with adhesion in the absence of competitors.

modes of interaction of TGF- $\beta$ to ECM components have been described, including thrombospondin (Murphy-Ullrich et al, 1992), fibronectin (Mooradian et al, 1989), collagen type IV (Paralkar et al, 1991), or proteoglycans like decorin, fibromodulin, biglycan, and betaglycan (Fukushima et al, 1993; Hildebrand et al, 1994). In addition, $\alpha_{2}$-macroglobulin is thought to be one of the major carrier proteins for TGF- $\beta$ in plasma (James 1990), and complex formation of TGF- $\beta$ isoforms with $\alpha_{2}$-macroglobulin can result in differential behavior of cells towards the growth factor. Although MLEC are not altered in their proliferation when exposed to TGF- $\beta 1$ in complex with $\alpha_{2}-$ macroglobulin, complex formation abolishes the effect of TGF- $\beta 2$ in the same assay (Danielpour and Sporn, 1990). In contrast, fibronectin, collagen, and betaglycan are thought to form non-neutralizing complexes 
with TGF- $\beta$, whereas decorin was described to inactivate growth factor activity (Yamaguchi et al, 1990). In all cases, however, particular binding regions for TGF- $\beta$ on the described components were not specified in detail.

Given the fact that a variety of ECM proteins serve as binding components for growth factors, we tested binding of TGF- $\beta$ to ECM, which was inhibited by soluble VN, whereas fibronectin or fibrinogen could not duplicate this effect. This initial observation already indicated that $\mathrm{VN}$ could serve as a major as yet unrecognized TGF- $\beta$ binding protein at these sites. Because neither preincubation of the ECM with a polyclonal anti-VN antibody nor removal of ECM/VNbound PAl-1 altered binding of TGF- $\beta$ to $\mathrm{ECM}$, it seems likely that TGF- $\beta$ and VN form a complex that could prevent TGF- $\beta$ from binding to other ligands in the ECM. In addition to TGF- $\beta 1$, other growth factors such as EGF, VEGF, and bFGF bound VN with variable efficiency, and this list was recently extended by the identification of VN as an insulin-like growth factor II binding protein (Upton et al, 1999). Furthermore, comparison of growth factor binding to the different $\mathrm{VN}$ isoforms revealed that multimeric forms of $\mathrm{VN}$ (predominantly present in the ECM and secreted by platelets) exhibit higher affinity than plasma VN for TGF- $\beta$. Heparin-binding VN multimers are thought to be the major reactive forms of the adhesive protein in connective tissue or on cell surfaces and may become deposited in the vessel wall upon vascular injury or during aging (Dufourcq et al, 1998; Mullins et al, 2000; Preissner 1991; Van Aken et al, 1997). Thus, binding to $\mathrm{VN}$ can potentially increase the local concentration of a respective growth factor at the cell-ECM interface and thereby influences its functions. In the present context, we concentrated on the interaction between TGF- $\beta$ and VN for several reasons: (a) both factors are contained within platelet $\alpha$-granules and become released upon activation; (b) the $\mathrm{VN}$ binding protein UPAR can associate with the insulin-like growth factor-II receptor, which is known as the latency TGF- $\beta$ binding protein (Nykjaer et al, 1998); (c) both proteins are abundant at sites of tissue remodeling and may have common target sites on vascular cells.

To further characterize the VN-TGF- $\beta$ interaction, glycosaminoglycans and PAl-1 were found to compete for binding of $\mathrm{VN}$ to immobilized growth factor, indicative of the participation of the aminoterminal portion of (multimeric) VN in binding. Since desulfated heparin and dermatan sulfate failed to compete the described association, highly ionic interactions between TGF- $\beta$ and VN, possibly involving the acidic region of $\mathrm{VN}$ (including sulfated Tyr56, Tyr59), may govern TGF- $\beta$ binding. These conclusions were corroborated by complementary results from limited digestion of VN to produce TGF- $\beta$ binding fragments of $\mathrm{VN}$ as well as from the identification of the peptide sequence 43 to 62 of VN to directly bind TGF- $\beta$. Together, these data strongly support our contention that the portion of the VN molecule downstream of the RGD epitope, which is in close proximity to (overlapping) binding sites for UPAR and PAI-1, serves as binding motif for TGF- $\beta$. Additional phosphorylation sites within this region of $\mathrm{VN}$ may contribute to the acidic nature of this TGF- $\beta$ binding site and could stabilize growth factor binding (Seger et al, 1998). In fact, VN is a natural substrate for ectokinases, which phosphorylate the adhesive protein upon platelet secretion and aggregation reactions (Gechtman and Shaltiel, 1997) with consequences for ligand binding to VN (Seger et al, 1998). Because of the fact that VN, PAl-1, and TGF- $\beta$ are stored in platelet $\alpha$-granules together with highly condensed glycosaminoglycans and become released upon platelet activation, high molecular weight complexes between VN and PAI-1 were found (Preissner et al, 1989), whereas no particular single complex with TGF- $\beta$ alone was discernible (data not shown). This may be a result of the fact that PAl-1 (and glycosaminoglycans) are in excess of TGF- $\beta$ upon platelet secretion reactions and thereby prevent stable complex formation between $\mathrm{VN}$ and TGF- $\beta$.

For testing the functional consequences related to the interaction of TGF- $\beta$ with VN in cell culture systems, a sensitive cellular assay for TGF- $\beta$ bioactivity was used (Abe et al, 1994). Upon preincubation of TGF- $\beta$ with multimeric VN there was hardly any significant alteration of TGF- $\beta$ activity with respect to induction of the PAl-1 promotor-driven luciferase construct. Although VN apparently does not influence the binding of TGF- $\beta$ to its cognate receptor and the subsequent activation of signal transduction pathways, VN may sequester TGF- $\beta$ into certain tissue compartments and thereby regulate its availability, activation, or degradation. This contention is particularly relevant in light of recent studies that showed a cooperation between the binding protein for latent TGF- $\beta$ (identical to insulin-like growth factor II receptor or mannose-6-phosphate receptor) and UPAR in TGF- $\beta$ conversion (Godar et al, 1999).

Another consequence of the TGF- $\beta$-VN interaction is the interference of TGF- $\beta$ in VN-mediated UPARand integrin-dependent cell adhesion, as demonstrated here. These antiadhesive properties of TGF- $\beta$ may influence inflammation processes as well as leukocyte recruitment or endothelial cell functions, because TGF- $\beta$ was shown to interfere with endothelial cell proliferation in a concentration-dependent manner (Takashima and Klagsbrun, 1996). Concentrations of TGF- $\beta$ required to exert these effects locally are believed to be available at sites of platelet activation/aggregation, inflammatory reactions, or neoplastic processes. However, TGF- $\beta$ concentrations in plasma are still controversially discussed (Grainger et al, 2000): because large amounts of TGF- $\beta$ are stored within platelets, which may become released upon activation at inflamed tissue sites, local TGF- $\beta$ concentrations may exceed those in plasma considerably. As an abundant pool of TGF- $\beta$, in $1 \mathrm{ml}$ of normal plasma $2 \times 10^{8}$ platelets have been found to secrete more than $40 \mu \mathrm{g}$ of TGF- $\beta$ (Jiang et al, 1995), such that complete platelet activation would give rise to those local TGF- $\beta$ concentrations used in the present study. Furthermore, the fact that TGF- $\beta$ serves as a very 
potent inducer of PAl-1 production together with the observation that PAl-1 could mobilize VN-bound TGF- $\beta$, points to an amplification loop eventually leading to prothrombotic or fibrotic vascular complications. Indeed, increased levels of PAI- 1 in patients are associated with a higher risk for developing thrombotic events (Wiman 1995) or increased resistance towards thrombolysis, and upon induction of vascular lesions in $\mathrm{PAl}_{-1}^{-1-}$ or $\mathrm{VN}^{-1-}$ mice, respectively, a more protected phenotype was observed as compared with wild-type mice (Eitzman et al, 2000; Konstantinides et al, 2001).

Interestingly, codistribution of VN, PAI- 1 , and TGF- $\beta$ in atherosclerotic tissue sections further provides evidence for the localization of these interacting proteins at inflamed tissue sites, such that VN may direct the deposition of the growth factor to tissues under pathophysiological conditions (data not shown). Together, these studies point to a new role for VN as a potential peptide growth factor binding protein in the ECM, the circulation, or on cell surfaces. The herein defined interaction of VN with TGF- $\beta$ may help to protect, sequester, or modulate its activity and can shed light on unexpected functions of this growth factor with regard to cellular adhesion.

\section{Materials and Methods}

\section{Materials}

TGF- $\beta 1$ and TGF- $\beta 2$ were obtained from Berlex (South San Francisco, California), EGF was kindly provided by Dr. L. Fryklund (University, Uppsala, Sweden), and bFGF was provided by Dr. L. Schweigerer (University of Essen, Essen, Germany). Fibrinogen was purified from plasma (Mahn and Muller-Berghaus, 1975), and VN was purified from pooled human plasma in its native protein conformation as described (Preissner et al, 1985). To obtain the multimeric form of $\mathrm{VN}$, plasma VN was incubated with $6 \mathrm{M}$ urea for 1 hour at $37^{\circ} \mathrm{C}$ followed by subsequent dialysis against Trisbuffered saline (TBS; $20 \mathrm{~mm}$ Tris, $\mathrm{pH} 7.4,150 \mathrm{~mm}$ $\mathrm{NaCl})$ to remove urea (Stockmann et al, 1993). The ternary VN-thrombin-antithrombin complex was provided by Dr. H. de Boer (University of Utrecht, Utrecht, The Netherlands); PAl-1 and plasmin were obtained from Dr. H. Pannekoek (Academic Medical Center, Amsterdam, The Netherlands). Active PAl-1 was generated by addition of $4 \mathrm{M}$ guanidinium chloride for 2 hours at $22^{\circ} \mathrm{C}$, followed by dialysis against TBS at $4^{\circ} \mathrm{C}$. VN was proteolyzed with plasmin at a VN/ enzyme ratio of $10: 1(\mathrm{w} / \mathrm{w})$ for the indicated time intervals at $37^{\circ} \mathrm{C}$. The reaction was stopped by addition of SDS-containing sample buffer (Laemmli, 1970). The VN-derived synthetic peptides comprising overlapping sequences of the aminoterminal region of $\mathrm{VN}$ (amino acids 1 to 130) were kindly provided by Dr. A. Jonczyk (Merck KGaA, Darmstadt, Germany). Single or two-chain high molecular weight kininogen was purchased from Enzyme Research Laboratories (South Bend, Indiana). UPA isolated from natural sources was from Medac (Hamburg, Germany), cyclic
RGDfV-peptide from Bachem (Heidelberg, Germany), and fibronectin from Sigma (Munich, Germany).

\section{Antibodies}

The monoclonal antibody against TGF- $\beta 1$ was obtained from Genzyme (Cambridge, Massachusetts), a rabbit polyclonal antibody against TGF- $\beta 1-3$ was obtained from Santa Cruz Biotechnology (Santa Cruz, California), and the monoclonal antibody VN7 against $\mathrm{VN}$ was obtained by standard hybridoma techniques (Stockmann et al, 1993). Monoclonal antibody R3 against UPAR was a kind gift from Dr. G. HoyerHansen (The Finsen Laboratory, Copenhagen, Denmark). The polyclonal antibody anti-S6/7 against VN was raised in rabbits, and the IgG fraction was isolated using established procedures (Preissner et al, 1985). After modification of the antibody with $\mathrm{N}$-hydroxysuccinimido-biotin as described (Preissner et al, 1989), detection was achieved by peroxidaseconjugated avidin (Dako, Hamburg, Germany). For detection of murine monoclonal antibodies, secondary goat and rabbit anti-mouse peroxidaseconjugated antibodies were used (Dako).

\section{Binding of TGF- $\beta$ to ECM}

HUVEC were grown to confluency on 96-well culture plates in DMEM containing $10 \%$ fetal calf serum. ECM was prepared by treating the cell monolayer with $0.5 \%$ (w/v) Triton $\mathrm{X}-100$ and $0.2 \mathrm{M} \mathrm{NH}_{3}$ as described (Mimuro and Loskutoff, 1989). ECM was subsequently blocked with $3 \%$ BSA in PBS for 1 hour at $22^{\circ} \mathrm{C}$, followed by washing with PBS containing $0.1 \%(\mathrm{w} / \mathrm{v})$ Tween 20 (PBS-Tween). Competitors were preincubated with TGF- $\beta 1$ for 30 minutes at $37^{\circ} \mathrm{C}$ before binding studies, and bound growth factor was detected by the monoclonal anti-TGF antibody and the respective secondary antibody.

\section{Binding Assays}

Binding of growth factors to VN was studied in an ELISA system using Maxisorp 96-well plates (Nunc, Wiesbaden, Germany). Growth factors were coated for 16 hours at a concentration of $2 \mu \mathrm{g} / \mathrm{ml}$ in coating buffer (15 mM Na $\mathrm{CO}_{3}, 35 \mathrm{~mm} \mathrm{NaHCO} 3, \mathrm{pH}$ 9.6) followed by blocking with $3 \%(\mathrm{w} / \mathrm{v})$ BSA in TBS for 1 hour at $22^{\circ} \mathrm{C}$. After three subsequent washes with PBS-Tween, plasma VN, the ternary VN complex, or multimeric VN were added in PBS containing $0.05 \%$ $(\mathrm{w} / \mathrm{v})$ Tween 20 and $1 \%(\mathrm{w} / \mathrm{v}) \mathrm{BSA}$ in a final volume of $50 \mu \mathrm{l}$ for 2 hours at $22^{\circ} \mathrm{C}$. After washing, bound VN was quantified by sequential incubation with the primary antibody VN7 $(1.5 \mu \mathrm{g} / \mathrm{ml})$ or biotinylated anti-VN (1:5000 dilution) in PBS-Tween for 1 hour at $22^{\circ} \mathrm{C}$ and peroxidase-conjugated secondary antibodies. Colorimetric detection was performed after incubation of wells with 2,2'-azino-di-(3-ethylbenzothiazoline) sulfate and $\mathrm{H}_{2} \mathrm{O}_{2}$ in $0.1 \mathrm{M}$ sodium acetate $/ 0.05 \mathrm{M}$ $\mathrm{NaH}_{2} \mathrm{PO}_{4}$ (pH 5.5) in a microtiter plate reader (BioRad, Munich, Germany) at an absorbance of $414 \mathrm{~nm}$. For competition experiments, glycosaminoglycans or 
PAl-1 were preincubated for 15 minutes at twice the final concentration before the addition of VN. Binding of soluble TGF- $\beta 1$ ( $2 \mu \mathrm{g} / \mathrm{ml})$ to coated plasma VN was followed by detection with a monoclonal anti-TGF- $\beta$ antibody ( $1 \mu \mathrm{g} / \mathrm{ml})$ and a goat anti-mouse peroxidaseconjugated secondary antibody (1:10,000 dilution). Before the addition of TGF- $\beta$, immobilized VN was preincubated with heparin $(100 \mu \mathrm{g} / \mathrm{ml})$ for 30 minutes, with either thorough washing of heparin-containing wells to remove unbound heparin or no washing. Binding of VN to noncoated plates showed less than $5 \%$ binding compared with growth factor-coated wells. Data are presented as mean \pm SEM of three independent experiments. For binding studies with immobilized VN-derived synthetic peptides, the Covalink system (Nunc) was used, exactly following the instructions of the manufacturer. Soluble TGF- $\beta 1$ was added in a final concentration of $500 \mathrm{ng} / \mathrm{ml}$ and detected by the monoclonal anti-TGF- $\beta$ antibody and the goat anti-mouse peroxidase-conjugated secondary antibody.

\section{Gel Electrophoretic Analysis and Immunoblotting}

SDS-polyacrylamide gel electrophoresis was performed using the buffer system described by Laemmli (Laemmli, 1970). After electrophoresis at $4^{\circ} \mathrm{C}$ for 2 hours in a mini-gel apparatus (Bio-Rad), proteins were transferred to nitrocellulose at $100 \mathrm{~V}$ for 2 hours, using the buffer system of Towbin (Towbin et al, 1979). After transfer, proteins were blocked by addition of $3 \%$ (w/v) BSA in PBS for 16 hours at $4^{\circ} \mathrm{C}$ followed by washing with PBS-Tween. Immunoblotting was performed by incubation with anti-VN (S6/7) as primary antibody (1:1000 dilution) for 2 hours in PBS-Tween at $22^{\circ} \mathrm{C}$ followed by incubation with the respective secondary antibody (peroxidase-conjugated, anti-rabbit IgG, 1:3000 dilution). For identification of TGF- $\beta 1$ binding to plasmin-digested VN fragments by ligand blotting, TGF- $\beta 1$ was incubated in PBS-Tween for 2 hours at $22^{\circ} \mathrm{C}$ before the addition of antibodies. Bound TGF- $\beta 1$ was detected by a monoclonal antibody against TGF- $\beta 1(1 \mu \mathrm{g} / \mathrm{ml})$ followed by the respective secondary antibody. Bands were visualized by using the enhanced chemiluminescence method (Amersham, Buckinghamshire, United Kingdom) according to the manufacturer's instructions. Blots were exposed to x-ray films (X-Omat AR; Kodak, Rochester, New York) for 10 to 30 seconds.

\section{MLEC-Based Activity Assay for TGF- $\beta$}

This assay (Abe et al, 1994) uses a stably transfected construct of a shortened PAI-1 promotor coupled to a luciferase reporter gene kindly provided by Dr. D. B. Rifkin (NYU Medical Center, New York, New York). Induction of the PAl-1 promotor by soluble TGF- $\beta$ leads to transcription of the luciferase gene and consecutively to emission of photons measured by a luminometer (LB 953 Autolumat; Berthold, Wildbad, Germany). Multimeric VN was preincubated with active TGF- $\beta 1$ for 30 minutes at $37^{\circ} \mathrm{C}$ in cell culture medium before addition to the cells. After incubation for 18 hours at $37^{\circ} \mathrm{C}$, lysis of MLEC was achieved by substrate and lysis buffer (Promega, Madison, Wisconsin) following the instructions of the manufacturer.

\section{Dissociation of VN-Bound TGF- $\beta$ by PAI-1}

Binding of TGF- $\beta$ to immobilized VN was followed by incubation of different concentrations of PAl-1 as indicated in the legend to Figure 6 to study the release of VN-bound growth factor. Unreleased TGF- $\beta$ was quantitated by incubation with a polyclonal anti-TGF- $\beta$ antibody followed by the respective secondary antibody as described above.

\section{Cell Culture}

BAF-3 (interleukin-3-dependent mouse B-cell line) cells were obtained from American Type Culture Collection (ATCC; Rockville, Maryland) and cultured in RPMI-1640 medium containing $10 \%$ fetal calf serum and $2 \mathrm{ng} / \mathrm{ml}$ interleukin-3. BAF-3 cells were transfected by electroporation with UPAR complementary DNA in the sense and antisense orientation using the expression vector pCDNA3. Cells were selected in the presence of $\mathrm{G} 418(1.2 \mathrm{mg} / \mathrm{ml})$ and found to express UPAR by fluorescence-activated cell sorter analysis, Northern blotting, and uPAR-enzyme linked immunosorbent assay (Chavakis et al, 1999, 2000). MG63 human osteosarcoma cells were obtained from ATCC and cultured in DMEM containing $10 \%$ fetal calf serum.

\section{Cell Adhesion Assay}

Cell adhesion of uPAR-transfected BAF-3 cells to VN-coated plates was tested according to a previously described protocol (Chavakis et al, 1999, 2000). Briefly, multiwell plates were coated with $2 \mu \mathrm{g} / \mathrm{ml}$ VN or $4 \mu \mathrm{g} / \mathrm{ml}$ fibronectin, respectively, and blocked with $3 \%(\mathrm{w} / \mathrm{v})$ BSA. UPAR-transfected BAF-3 cells or MG63 cells were washed in serum-free RPMI or DMEM, respectively, and plated onto the precoated wells for 60 minutes at $37^{\circ} \mathrm{C}$ in the absence or presence of competitors in serum-free RPMI or DMEM, respectively. After the incubation period, the wells were washed and the number of adherent cells were quantified by crystal-violet staining at $590 \mathrm{~nm}$.

\section{Statistical Analysis}

Triplicate values were compared using the Student's $t$ test. Probability values $<0.05$ were regarded as significant.

\section{Acknowledgements}

We are grateful to Mr. Thomas Schmidt-Wöll and Ms. Susanne Tannert-Otto for their skillful technical assistance. 


\section{References}

Abe M, Harpel JG, Metz CN, Nunes I, Loskutoff DJ, and Rifkin DB (1994). An assay for transforming growth factor- $\beta$ using cells transfected with a plasminogen activator inhibitor-1 promotor-luciferase construct. Anal Biochem 216: 276-284.

Bittdorf SV, Williams EC, and Mosher DF (1993). Characterization of changes induced by treatment with urea. J Biol Chem 268:24838-24846.

Chavakis T, Kanse SM, Lupu F, Hammes HP, Muller-Esterl W, Pixley RA, Colman RW, and Preissner KT (2000). Different mechanisms define the antiadhesive function of high molecular weight kininogen in integrin- and urokinase receptordependent interactions. Blood 96:514-522.

Chavakis T, May EA, Preissner KT, and Kanse S (1999). Molecular mechanisms of zinc-dependent leucocyte adhesion involving the urokinase receptor and $\beta_{2}$-integrins. Blood 93:2976-2983.

Casaroli Marano RP, Preissner KT, and Vilaro S (1995). Fibronectin, laminin, vitronectin and their receptors at newlyformed capillaries in proliferative diabetic retinopathy. Exp Eye Res 60:5-17.

Ciambrone GJ and McKeown-Longo PJ (1990). Plasminogen activator inhibitor type I stabilizes vitronectin-dependent adhesions in HT-1080 cells. J Cell Biol 111:2183-2195.

Danielpour D and Sporn MB (1990). Differential inhibition of transforming growth factor $\beta 1$ and $\beta 2$ activity by $\alpha_{2}$ macroglobulin. J Biol Chem 275:6973-6977.

Declerck PJ, de Mol M, Alessi MC, Baudner S, Paques EP, Preissner KT, Muller-Berghaus G, and Collen D (1988). Purification and characterization of a plasminogen activator inhibitor 1 binding protein from human plasma: Identification as a multimeric form of S-protein (vitronectin). J Biol Chem 263:15454-15461.

Dufourcq P, Louis H, Moreau C, Daret D, Boisseau MR, Lamaziere JM, and Bonnet J (1998). Vitronectin expression and interaction with receptors in smooth muscle cells from human atheromatous plaque. Arterioscler Thromb Vasc Biol 18:168-176.

Eitzman DT, Westrick RJ, Nabel EG, and Ginsburg D (2000). Plasminogen activator inhibitor-1 and vitronectin promote vascular thrombosis in mice. Blood 95:577-580.

François PP, Preissner KT, Herrmann M, Haugland RP, Vaudaux P, Lew DP, and Krause KH (1999). Vitronectin interaction with glycosaminoglycans. J Biol Chem 274: 37611-37619.

Fukushima D, Butzow R, Hildebrand A, and Ruoslahti E (1993). Localization of transforming growth factor $\beta$ binding site in betaglycan: Comparison with small extracellular matrix proteoglycans. J Biol Chem 268:22710-22715.

Gechtman Z and Shaltiel S (1997). Phosphorylation of vitronectin on Ser362 by protein kinase $C$ attenuates its cleavage by plasmin. Eur J Biochem 243:493-501.

Godar S, Horejsi V, Weidle UH, Binder BR, Hansmann C, and Stockinger H (1999). M6P/IGFII-receptor complexes urokinase receptor and plasminogen for activation of transforming growth factor- $\beta 1$. Eur J Immunol 29:1004-1013.

Grainger DJ, Mosedale DE, and Metcalfe JC (2000). TGF- $\beta$ in blood: A complex problem. Cytokine Growth Factor Rev 11:133-145.
Hildebrand A, Romaris M, Rasmussen LM, Heinegard D, Twardzik DR, Border WA, and Ruoslahti E (1994). Interaction of the small interstitial proteoglycans biglycan, decorin and fibromodulin with transforming growth factor $\beta$. Biochem J 302:527-534.

James K (1990). Interactions between cytokines and $\alpha_{2}$ macroglobulin. Immunol Today 11:163-166.

Jiang X, Kanai H, Hiromura K, Sawamura M, and Yano S (1995). Increased intraplatelet and urinary transforming growth factor- $\beta$ in patients with multiple myeloma. Acta Haematol 94:1-6.

Kan M and Shi EG (1990). Fibronectin, not laminin, mediates heparin-dependent heparin-binding growth factor type I binding to substrata and stimulation of endothelial cell growth. In Vitro Cell Dev Biol 26:1151-1156.

Kjoller L, Kanse SM, Kirkegaard T, Rodenburg KW, Ronne E, Goodman SL, Preissner KT, Ossowski L, and Andreasen PA (1997). Plasminogen activator inhibitor-1 represses integrinmediated cell migration independently of its function as an inhibitor of plasminogen activation. Exp Cell Res 232:420-429.

Klagsbrun M and Baird A (1991). A dual receptor system is required for basic fibroblast growth factor activity. Cell 67: 229-231.

Konstantinides S, Schafer K, Thinnes T, and Loskutoff DJ (2001). Plasminogen activator inhibitor-1 and its cofactor vitronectin stabilize arterial thrombi after vascular injury in mice. Circulation 103:576-583.

Kost C, Stuber W, Ehrlich H, Pannekoek H, and Preissner KT (1992). Mapping of binding sites for heparin, plasminogen activator inhibitor-1, and plasminogen to vitronectin's heparin-binding region reveals a novel vitronectin-dependent feedback mechanism for the control of plasmin formation. J Biol Chem 267:12098-12105.

Kramer MD, Gissler HM, Weidenthaler-Barth B, and Preissner KT (1993). Vitronectin and plasmin(ogen) in lesional skin of the bullous pemphigoid: colocalization suggests binding interactions. In: Preissner KT, Rosenblatt S, Kost C, Wegerhoff $\mathrm{J}$, and Mosher DF, editors. Biology of vitronectins and their receptors. Amsterdam: Elsevier, 295-301.

Laemmli UK (1970). Cleavage of structural proteins during the assembly of the head of bacteriophage T4. Nature 227:680-685.

Mahn I and Muller-Berghaus G (1975). Studies on catabolism of ${ }^{125}$ I-labelled fibrinogen in normal rabbits and in rabbits with indwelling intravenous catheters: methodologic aspects. Haemostasis 4:41-50.

Massague $J$ (1990). The transforming growth factor- $\beta$ family. Annu Rev Cell Biol 6:597-641.

Massague J (1998). TGF- $\beta$ signal transduction. Annu Rev Biochem 67:753-791.

Mimuro J and Loskutoff DJ (1989). Binding of type 1 plasminogen activator inhibitor to the extracellular matrix of cultured bovine endothelial cells. J Biol Chem 264:5058-5063.

Mooradian DL, Lucas RC, Weatherbee JA, and Furcht LT (1989). Transforming growth factor $\beta-1$ binds to immobilized fibronectin. J Cell Biochem 41:189-200.

Mori M, Iwasaki K, Sato R, Komine Y, Imanaka T, and Takano $\mathrm{T}$ (1995). The 66, 56, 50 and $47 \mathrm{kDa}$ vitronectins in atherosclerotic lesions and in serum. Ann N Y Acad Sci 748:524525. 
Mullins RF, Russell SR, Anderson DH, and Hageman GS (2000). Drusen associated with aging and age-related macular degeneration contain proteins common to extracellular deposits associated with atherosclerosis, elastosis, amyloidosis, and dense deposit disease. FASEB J 14:835-846.

Munger JS, Harpel JG, Gleizes PE, Mazzieri R, Nunes I, and Rifkin DB (1997). Latent transforming growth factor- $\beta$ : structural features and mechanisms of activation. Kidney Int $51: 1376-1382$

Murphy-Ullrich JE, Schultz-Cherry S, and Hook M (1992). Transforming growth factor- $\beta$ complexes with thrombospondin. Mol Biol Cell 3:181-188.

Neufeld G, Cohen T, Gengrinovitch S, and Poltorak Z (1999). Vascular endothelial growth factor (VEGF) and its receptors. FASEB J 13:9-22.

Nykjaer A, Christensen El, Vorum H, Hager H, Petersen CM, Roigaard H, Min HY, Vilhardt F, Moller LB, Kornfeld S, and Gliemann J (1998). Mannose 6-phosphate/insulin-like growth factor-II receptor targets the urokinase receptor to lysosomes via a novel binding interaction. J Cell Biol 141:815828.

Paralkar VM, Vukicevic S, and Reddi AH (1991). Transforming growth factor $\beta$ type 1 binds to collagen IV of basement membrane matrix: implications for development. Dev Biol 143:303-308.

Preissner KT (1991). Structure and biological role of vitronectin. Annu Rev Cell Biol 7:275-310.

Preissner KT, Holzhuter S, Justus C, and Muller-Berghaus G (1989). Identification and partial characterization of platelet vitronectin: Evidence for complex formation with plateletderived plasminogen activator inhibitor-1. Blood 74:19891996.

Preissner KT, Wassmuth R, and Muller-Berghaus G (1985). Physicochemical characterization of human S-protein and its function in the blood coagulation system. Biochem $\mathrm{J} 231$ : 349-355.

Raines EW, Lane TF, Iruela-Arispe ML, Ross R, and Sage H (1992). The extracellular glycoprotein SPARC interacts with platelet-derived growth factor (PDGF)-AB and -BB and inhibits the binding of PDGF to its receptor. Proc Natl Acad Sci USA 89:1281-1285.

Rapraeger AC, Krufka A, and Olwin BB (1991). Requirement of heparan sulfate for bFGF-mediated fibroblast growth and myoblast differentiation. Science 252:1705-1708.
Roghani M, Mansukhani A, Dell'Era P, Bellosta P, Basilico C, Rifkin DB, and Moscatelli D (1994). Heparin increases the affinity of basic fibroblast growth factor for its receptor but is not required for binding. J Biol Chem 269:3976-3984.

Seger D, Gechtman Z, and Shaltiel S (1998). Phosphorylation of vitronectin by casein kinase II. J Biol Chem 273:2480524813.

Stefansson S and Lawrence DA (1996). The serpin PAl-1 inhibits cell migration by blocking integrin $\alpha_{\mathrm{V}_{\beta 3}}$ binding to vitronectin. Nature 383:441-443.

Stockmann A, Hess S, Declerck P, Timpl R, and Preissner KT (1993). Multimeric vitronectin. J Biol Chem 268:2287422882.

Takashima S and Klagsbrun M (1996). Inhibition of endothelial cell growth by macrophage-like U-937 cell-derived oncostatin $\mathrm{M}$, leukemia inhibitory factor, and transforming growth factor $\beta 1$. J Biol Chem 271:24901-24906.

Towbin H, Staehelin T, and Gordon J (1979). Electrophoretic transfer of proteins from polyacrylamide gels to nitrocellulose sheets: procedure and some applications. Proc Natl Acad Sci USA 76:4350-4354.

Upton Z, Webb H, Hale K, Yandell CA, McMurtry JP, Francis GL, and Ballard FJ (1999). Identification of vitronectin as a novel insulin-like growth factor-II binding protein. Endocrinology 140:2928-2931.

Van Aken BE, Seiffert D, Thinnes T, and Loskutoff DJ (1997). Localization of vitronectin in the normal and atherosclerotic human vessel wall. Histochem Cell Biol 107:313-320.

Wiman B (1995). Plasminogen activator inhibitor 1 (PAl-1) in plasma: its role in thrombotic disease. Thromb Haemost 74:71-76.

Wong A, Hwang SM, McDevitt P, Stadel JM, and Johanson K (1996). Studies on $\alpha_{\mathrm{V}_{\beta} 3} /$ ligand interactions using a [3H]SK\&F107260 binding assay. Mol Pharmacol 50:529-537.

Yamaguchi Y, Mann DM, and Ruoslahti E (1990). Negative regulation of transforming growth factor- $\beta$ by the proteoglycan decorin. Nature 346:281-284.

Yayon A, Klagsbrun M, Esko JD, Leder P, and Ornitz DM (1991). Cell surface, heparin-like molecules are required for binding of basic fibroblast growth factor to its high affinity receptor. Cell 64:841-848. 